\title{
The common $S L C 30 A 8$ Arg325Trp variant is associated with reduced first-phase insulin release in 846 non-diabetic offspring of type 2 diabetes patients-the EUGENE2 study
}

\author{
T. W. Boesgaard $\cdot$ J. Žilinskaitė • M. Vänttinen • \\ M. Laakso • P.-A. Jansson • A. Hammarstedt • \\ U. Smith • N. Stefan • A. Fritsche • H. Häring • \\ M. Hribal • G. Sesti • D. P. Zobel • O. Pedersen • \\ T. Hansen • for the EUGENE 2 Consortium
}

Received: 3 October 2007 / Accepted: 18 January 2008/Published online: 7 March 2008

(C) Springer-Verlag 2008

\begin{abstract}
Aims/hypothesis A recent genome-wide association study identified the SLC30A8 rs13266634 polymorphism encoding an Arg325Trp polymorphism in the zinc transporter protein member 8 (ZnT-8) to be associated with type 2 diabetes. Here,
\end{abstract}

Electronic supplementary material The online version of this article (doi:10.1007/s00125-008-0955-6) contains supplementary material, which is available to authorised users.

T. W. Boesgaard $(\bowtie) \cdot$ D. P. Zobel $\cdot$ O. Pedersen $\cdot$ T. Hansen

Steno Diabetes Center,

Niels Steensens Vej 1, NLC2.12,

DK-2820 Gentofte, Copenhagen, Denmark

e-mail: tweb@steno.dk

J. Žilinskaitè · M. Vänttinen · M. Laakso

Department of Medicine, University of Kuopio,

Kuopio, Finland

P.-A. Jansson · A. Hammarstedt • U. Smith

The Lundberg Laboratory for Diabetes Research,

Department of Internal Medicine, Sahlgrenska University Hospital,

Gothenburg, Sweden

N. Stefan $\cdot$ A. Fritsche $\cdot$ H. Häring

Department of Internal Medicine,

Division of Endocrinology, Diabetology, Nephrology,

Vascular Medicine and Clinical Chemistry,

University of Tubingen,

Tubingen, Germany

M. Hribal · G. Sesti

Department of Experimental and Clinical Medicine,

University Magna Græcia of Catanzaro,

Catanzaro, Italy

O. Pedersen

Faculty of Health Science, University of Aarhus,

Aarhus, Denmark we investigate whether the polymorphism is related to altered insulin release in response to intravenous and oral glucose loads in non-diabetic offspring of type 2 diabetic patients. Methods We genotyped SLC30A8 rs13266634 in 846 nondiabetic offspring of type 2 diabetic patients from five different white populations: Danish $(n=271)$, Finnish $(n=217)$, German $(n=149)$, Italian $(n=109)$ and Swedish $(n=100)$. Participants were subjected to both IVGTTs and OGTTs, and measurements of insulin sensitivity. Results Homozygous carriers of the major type 2 diabetes $\mathrm{C}$ risk-allele showed a $19 \%$ decrease in first-phase insulin release $(0-10 \mathrm{~min})$ measured during the IVGTT (CC 3,624 3,197; CT 3,763 $\pm 2,674$; TT 4,478 $\pm 3,032 \mathrm{pmol} \mathrm{l}^{-1} \mathrm{~min}^{-1}$, mean $\pm \mathrm{SD} ; p=0.007)$. We found no significant genotype effect on insulin release measured during the OGTT or on estimates of insulin sensitivity.

Conclusions/interpretation Of European non-diabetic offspring of type 2 diabetes patients, $46 \%$ are homozygous carriers of the Arg325Trp polymorphism in ZnT-8, which is known to associate with type 2 diabetes. These diabetesprone offspring are characterised by a $19 \%$ decrease in firstphase insulin release following an intravenous glucose load, suggesting a role for this variant in the pathogenesis of pancreatic beta cell dysfunction.

Keywords Beta cell dysfunction - Genetics · Insulin . Offspring · Polymorphism - SLC30A8 - Type 2 diabetes . Zinc transporter protein member $8 \cdot \mathrm{ZnT}-8$

$\begin{array}{ll}\text { Abbreviations } \\ \text { HOMA-IR } & \begin{array}{l}\text { homeostasis model assessment of insulin } \\ \text { resistance }\end{array} \\ \text { ZnT-8 } & \begin{array}{l}\text { zinc transporter protein member } 8 \\ \text { Hon }\end{array}\end{array}$

Abbreviations

ZnT-8 zinc transporter protein member 8 


\section{Introduction}

Type 2 diabetes is a common and often disabling condition [1] resulting from a complex interaction between genetic and environmental factors that cause two major pathophysiological features: impaired pancreatic beta cell function and insulin resistance [2]. Recently, a genome-wide association study showed that an Arg325Trp polymorphism in SLC30A8 (rs13266634) associates with type 2 diabetes with an OR of $1.52 \pm 0.31, p=5 \times 10^{-7}$ [3]. Similar findings have been provided by other independent genome-wide association studies [4, 5] and replicated in four case-control studies [6-9]. SLC30A8, located on chromosome 8q24.11, is exclusively expressed in pancreas and mainly in the beta cell [10]. SLC30A8 encodes a zinc transporter protein member 8 (ZnT-8), which is localised in insulin secretory granules [10] and is important for maturation, storage and secretion of insulin from beta cells $[11,12]$. One study showed that the major risk $\mathrm{C}$ allele of rs13266634, which confers increased risk of type 2 diabetes, was associated with decreased insulin release during an OGTT in 3,982 middle-aged people of the general Danish population [4]. In contrast, two other studies of 1,276 and 921 non-diabetic individuals, respectively, found that risk-allele carriers did not show reduced insulin release after an oral glucose load $[13,14]$. However, in a sub sample of 150 individuals from the latter study, reduced insulin release upon intravenous glucose stimulation was demonstrated [14].

We aimed to investigate whether SLC30A8 rs13266634 has an impact on insulin release following intravenous or oral glucose loads in a relatively large study sample of European non-diabetic offspring of parents with type 2 diabetes.

\section{Methods}

Participants All participants included in this study were healthy non-diabetic offspring of parents with type 2 diabetes.
For inclusion, one of the parents had to have type 2 diabetes and the other parent normal glucose tolerance evaluated by an OGTT or a lack of history of type 2 diabetes. The probands were recruited from five study centres in Europe. Altogether, 846 non-diabetic offspring were included in the study as follows: Danish $(n=271)$, Finnish $(n=217)$, German $(n=149)$, Italian $(n=109)$ and Swedish $(n=100)$. Clinical and biochemical characteristics of the study population are shown in Table 1.

The study protocol was approved by appropriate Institutional Review Boards and was in accordance with the Helsinki Declaration II. All study participants gave informed consent.

Biochemical and anthropometric measures All study centres followed the same protocol. Fasting blood samples were drawn after $12 \mathrm{~h}$ of fasting followed by an OGTT (75 $\mathrm{g}$ glucose) to evaluate glucose tolerance status and OGTT-related insulin release (samples for measurement of plasma glucose and serum insulin were drawn at 0, 30, 90 and $120 \mathrm{~min}$ ). On the second occasion after $12 \mathrm{~h}$ of fasting an IVGTT was performed to determine the first-phase $(0-10 \mathrm{~min})$ insulin release. A bolus of glucose $(300 \mathrm{mg} / \mathrm{kg}$ in a $50 \%$ solution) was given within $30 \mathrm{~s}$ into the antecubital vein. Samples for the measurement of plasma glucose and insulin (arterialised venous blood) were drawn at $-5,0,2,4,6,8,10,20,30,40,50$ and $60 \mathrm{~min}$. At $60 \mathrm{~min}$ after the glucose bolus a hyperinsulinaemic-euglycaemic clamp was initiated (insulin infusion: $240 \mathrm{pmol} \mathrm{m}^{-2} \mathrm{~min}^{-1}$ for $120 \mathrm{~min}$ ) to evaluate insulin sensitivity [15]. Glucose was clamped at $5.0 \mathrm{mmol} / \mathrm{l}$ for the next $120 \mathrm{~min}$ by infusion of $20 \%$ glucose at various rates according to glucose measurements performed at $5 \mathrm{~min}$ intervals. In the Copenhagen centre, the euglycaemic clamp was not performed. Instead, all individuals underwent a 33-point tolbutamide-modified, frequently sampled IVGTT. Insulin sensitivity index ( $\mathrm{Si}$ ) was calculated using the Bergman MINMOD computer programme [16]. Blood pressure was measured in a sitting position after a 5 min rest with a mercury sphygmomanometer. Height and weight were measured to the nearest $0.5 \mathrm{~cm}$ and $0.1 \mathrm{~kg}$,

Table 1 Anthropometrical and metabolic characteristics of 846 non-diabetic offspring of type 2 diabetes patients stratified according to EUGENE2 study centre

\begin{tabular}{|c|c|c|c|c|c|c|}
\hline Characteristic & $\begin{array}{l}\text { Swedish } \\
\text { Gothenburg } \\
(n=100)\end{array}$ & $\begin{array}{l}\text { Italian } \\
\text { Catanzaro } \\
(n=109)\end{array}$ & $\begin{array}{l}\text { Danish } \\
\text { Copenhagen } \\
(n=271)\end{array}$ & $\begin{array}{l}\text { Finnish } \\
\text { Kuopio } \\
(n=217)\end{array}$ & $\begin{array}{l}\text { German } \\
\text { Tübingen } \\
(n=149)\end{array}$ & $p$ value \\
\hline Men/women $(n)$ & $24 / 76$ & $41 / 68$ & $117 / 154$ & $104 / 113$ & $83 / 66$ & $<0.001$ \\
\hline Age (years) & $40.0 \pm 7.2$ & $38.2 \pm 10.7$ & $42.3 \pm 11.6$ & $35.2 \pm 6.2$ & $44.5 \pm 10.5$ & $<0.001$ \\
\hline BMI $\left(\mathrm{kg} / \mathrm{m}^{2}\right)$ & $24.8 \pm 3.5$ & $28.5 \pm 6.0$ & $26.3 \pm 4.7$ & $26.2 \pm 4.7$ & $27.9 \pm 5.2$ & $<0.001$ \\
\hline Fasting plasma glucose $(\mathrm{mmol} / \mathrm{l})$ & $4.8 \pm 0.4$ & $4.9 \pm 0.7$ & $5.2 \pm 0.5$ & $5.2 \pm 0.4$ & $5.1 \pm 0.5$ & $<0.001$ \\
\hline 2-h plasma glucose $(\mathrm{mmol} / \mathrm{l})$ & $6.3 \pm 1.5$ & $6.0 \pm 1.6$ & $6.1 \pm 1.6$ & $6.3 \pm 1.4$ & $6.5 \pm 1.6$ & 0.082 \\
\hline Fasting serum insulin (pmol/1) & $45 \pm 22$ & $75 \pm 127$ & $46 \pm 40$ & $44 \pm 33$ & $54 \pm 35$ & $<0.001$ \\
\hline 2-h serum insulin $(\mathrm{pmol} / \mathrm{l})$ & $290 \pm 275$ & $350 \pm 368$ & $310 \pm 295$ & $317 \pm 247$ & $387 \pm 305$ & 0.042 \\
\hline
\end{tabular}

Data are mean \pm SD

Plasma glucose and serum insulin levels were measured in the fasting state and at $2 \mathrm{~h}$ after an OGTT 
respectively. BMI was calculated as weight $(\mathrm{kg})$ divided by height (m) squared.

Glucose was measured by each centre and determined by standard laboratory methods. Because plasma insulin was measured by different methods (except for the Gothenburg centre, which had insulin measured in Tübingen), the assay applied in Tübingen (micro-particle enzyme immunoassay; Abbott Laboratories, Tokyo, Japan) was selected as a reference assay. Catanzaro, Copenhagen and Kuopio centres sent 40 to 100 fasting and post-glucose challenge plasma insulin samples to Tübingen for parallel analyses. Plasma insulin levels from these three centres were converted to plasma insulin levels corresponding to the Tübingen assay by linear regression analysis.

Genotyping Screening of rs13266634 was performed with the TaqMan Allelic Discrimination Assays (Applied Biosystems, Foster City, CA, USA). The genotype distributions in the individual study samples are given in Table 2. The overall genotyping success rate was $100 \%$; re-screening of $6.3 \%$ of samples gave $100 \%$ identical results. Genotype distributions obeyed Hardy-Weinberg equilibrium.

Statistical analysis Data analyses were performed using Statistical Package for Social Science (SPSS, Chicago, IL, USA) version 14.0. The results for continuous variables are given as means $\pm \mathrm{SD}$. A value of $p<0.05$ was considered to be significant. Insulin levels were logarithmically transformed prior to statistical analysis. The incremental area under the insulin curve during an IVGTT was calculated by the trapezoidal method. Homeostasis model assessment of insulin resistance (HOMA-IR) was calculated as described earlier [17]. The differences between the groups were assessed by ANOVA for continuous variables and by the $\chi^{2}$ test for noncontinuous variables. Linear mixed model analysis was applied to adjust for confounding factors. For mixed model analysis we included the centre and pedigree (coded as a family number) as random factors, the genotype and sex as fixed factors, and age and BMI as covariates.

\section{Results}

The SLC30A8 rs13266634 genotype and allele frequencies for the individual EUGENE2 study cohorts are summarised in Table 2. Although all analyses were corrected for recruitment centre, we compared genotype and allele frequencies and found a significant difference between cohorts. The type 2 diabetes-linked $\mathrm{CC}$ genotype of SLC30A8 rs13266634, which had an overall frequency of $46 \%$ in non-diabetic offspring of type 2 diabetic patients, was associated with decreased first-phase insulin release during an IVGTT (CC 3,624 $\pm 3,197$, CT 3,763 $\pm 2,674$, TT 4,478 \pm $3,032 \mathrm{pmol}^{-1} \min ^{-1}[$ mean $\pm \mathrm{SD}], p=0.007$ ) (Table 3, Fig. 1d; Electronic supplementary material [ESM] Table 1). Peak plasma insulin levels measured during an IVGTT at 4 min were reduced by $25 \%$ in homozygous major allele carriers (CC $431 \pm 365$, CT $460 \pm 335$, TT $573 \pm 399 \mathrm{pmol} / \mathrm{l}$ ) [mean \pm SD] (Fig. 1d). We found no association between the SLC30A8 rs13266634 genotypes and second-phase IVGTT insulin release (Table 3, Fig. 1d), OGTT insulin release (Fig. 1b) or insulin sensitivity as measured by a hyperinsulinaemic-euglycaemic clamp, insulin sensitivity index calculated using the Bergman MINMOD computer programme (ESM Table 1) or HOMA-IR (Table 3). In addition, we did not detect any significant impact of the genotype on plasma glucose levels during the IVGTT or the OGTT (Fig. 1a,c).

\section{Discussion}

In the present study of 846 European participants, each of whom had one type 2 diabetic parent, we demonstrate that homozygous carriers $(46 \%$ of the examined study population) of the major risk $\mathrm{C}$ allele of SLC30A8 are characterised by a $19 \%$ decrease in first-phase insulin release during an IVGTT. No differences in insulin release during the second phase of the IVGTT or in insulin sensitivity were shown. Our findings indicate that the findings of previous studies of

Table 2 SLC30A8 rs13266634 genotype distributions and major risk-allele frequencies in individual EUGENE2 study cohorts

\begin{tabular}{|c|c|c|c|c|c|c|}
\hline Genotype distribution & $\begin{array}{l}\text { Swedish } \\
\text { Gothenburg } \\
(n=100)\end{array}$ & $\begin{array}{l}\text { Italian } \\
\text { Catanzaro } \\
(n=109)\end{array}$ & $\begin{array}{l}\text { Danish } \\
\text { Copenhagen } \\
(n=271)\end{array}$ & $\begin{array}{l}\text { Finnish } \\
\text { Kuopio } \\
(n=217)\end{array}$ & $\begin{array}{l}\text { German } \\
\text { Tübingen } \\
(n=149)\end{array}$ & $p$ value \\
\hline $\mathrm{CC}, n(\%)$ & $43(43)$ & $69(63)$ & $128(47)$ & $74(34)$ & $78(52)$ & $<0.001$ \\
\hline $\mathrm{CT}, n(\%)$ & $48(48)$ & $37(34)$ & $103(38)$ & $97(45)$ & $56(38)$ & \\
\hline $\mathrm{TT}, n(\%)$ & $9(9)$ & $3(3)$ & $40(5)$ & $46(21)$ & $15(10)$ & \\
\hline $\begin{array}{l}\text { Major risk-allele frequency, \% } \\
\qquad(95 \% \mathrm{CI})\end{array}$ & $67(60.5-73.5)$ & $80.3(75.0-86.5)$ & $66.2(62.3-70.3)$ & $56.5(51.8-61.1)$ & $71.3(66.0-76.3)$ & $<0.001$ \\
\hline
\end{tabular}

Genotype data are number $(n)$ of participants with each genotype (\% of each group) and major risk-allele frequencies in per cent $(95 \% \mathrm{CI})$ according to study cohort 
Table 3 Anthropometrical and metabolic characteristics of 846 non-diabetic offspring with one type 2 diabetic parent, stratified according to the SLC30A8 Arg325Trp genotype

\begin{tabular}{|c|c|c|c|c|}
\hline Characteristic & $\mathrm{CC}(n=392)$ & CT $(n=341)$ & $\mathrm{TT}(n=113)$ & $p$ value \\
\hline Men/women $(n)$ & $176 / 216$ & $134 / 207$ & $59 / 54$ & \\
\hline Age (years) & $40.6 \pm 10.3$ & $39.8 \pm 10.5$ & $39.2 \pm 9.2$ & 0.2 \\
\hline BMI $\left(\mathrm{kg} / \mathrm{m}^{2}\right)$ & $26.4 \pm 5.0$ & $26.9 \pm 5.2$ & $26.7 \pm 4.6$ & 0.3 \\
\hline HOMA-IR & $11.9 \pm 20.4$ & $12.0 \pm 9.8$ & $10.6 \pm 8.3$ & 0.1 \\
\hline \multicolumn{5}{|l|}{ Insulin release } \\
\hline First phase $\left(\mathrm{pmol} \mathrm{l}^{-1} \mathrm{~min}^{-1}\right)$ & $3,624 \pm 3,197$ & $3,763 \pm 2,674$ & $4,478 \pm 3,032$ & 0.007 \\
\hline Second phase (pmol $\left.1^{-1} \min ^{-1}\right)$ & $10,567 \pm 10,433$ & $11,603 \pm 10,705$ & $11,252 \pm 10,025$ & 0.2 \\
\hline Insulin AUC during OGTT $([\mathrm{pmol} / 1] \times \min )$ & $245,005 \pm 157,390$ & $264,333 \pm 177,020$ & $261,999 \pm 187,453$ & 0.2 \\
\hline
\end{tabular}

Data are mean $\pm \mathrm{SD}$

Calculated $p$ values were adjusted for family relationship, study centre, sex, age and BMI (where appropriate)

common, multifactorial forms of type 2 diabetes, for which an association with SLC30A8 Arg325Trp has been consistently documented, are likely to be explained by a gene variant causing pancreatic beta cell dysfunction.

A previous study of 3,982 non-diabetic middle-aged people of the general Danish population reported a decrease in insulin release after an oral glucose load among $\mathrm{C}$ allele carriers [4]. In contrast, in the present study and in two other studies of 1,276 and 921 non-diabetic individuals, respectively, reduced insulin release after an oral glucose load could not be demonstrated $[13,14]$. Interestingly, in a sub-study of 150 healthy individuals in the German study [14], the C allele was shown to associate with reduced insulin release upon intravenously administered glucose. The discrepancy between the association of SLC30A8 rs13266634 with glucose-stimulated insulin release during the IVGTT and the lack of association with insulin release after an oral glucose load in the same people is unexplained, but might be due to compensatory mechanisms

Fig. 1 a, b Plasma glucose and serum insulin responses in relation to the genotypes $\mathrm{CC}$, $\mathrm{CT}$ and TT of the SLC30A8 rs13266634 in 846 non-diabetic offspring of type 2 diabetic patients during a $75 \mathrm{~g} \mathrm{WHO}$ standardised OGTT. c, d Plasma glucose and serum insulin responses in relation to the same genotypes during an IVGTT. Circles, CC genotype; triangles, CT genotype: squares,

TT genotype. Values are given as mean $\pm \mathrm{SEM}$ involving increased incretin secretion and/or incretin effect after orally administered glucose. Another possible explanation might be lack of statistical power to detect a beta cell defect upon an oral glucose load. In the total cohort of 846 nondiabetic persons, our data indicate that the effect of the SLC30A8 rs 13266634 is less than $18 \%$ of a standard deviation.

SLC30A8 encodes a zinc transporter, ZnT-8, which in both humans and mice is exclusively produced in pancreas, mainly in beta cells $[10,18,19]$. It is localised to insulin secretory granules $[10,12,20]$, where it facilitates the accumulation of zinc from the cytoplasm into intracellular vesicles and is implicated in secretion of insulin from beta cells $[18,20-23]$. Our data show that the acute insulin release after an intravenous glucose load is severely reduced, indicating that the function and/or production of ZnT-8 are reduced in carriers of the common risk C-allele of SLC30A8. It is likely that the risk $\mathrm{C}$ allele or a tightly linked causative variant also modulates the function of neighbouring
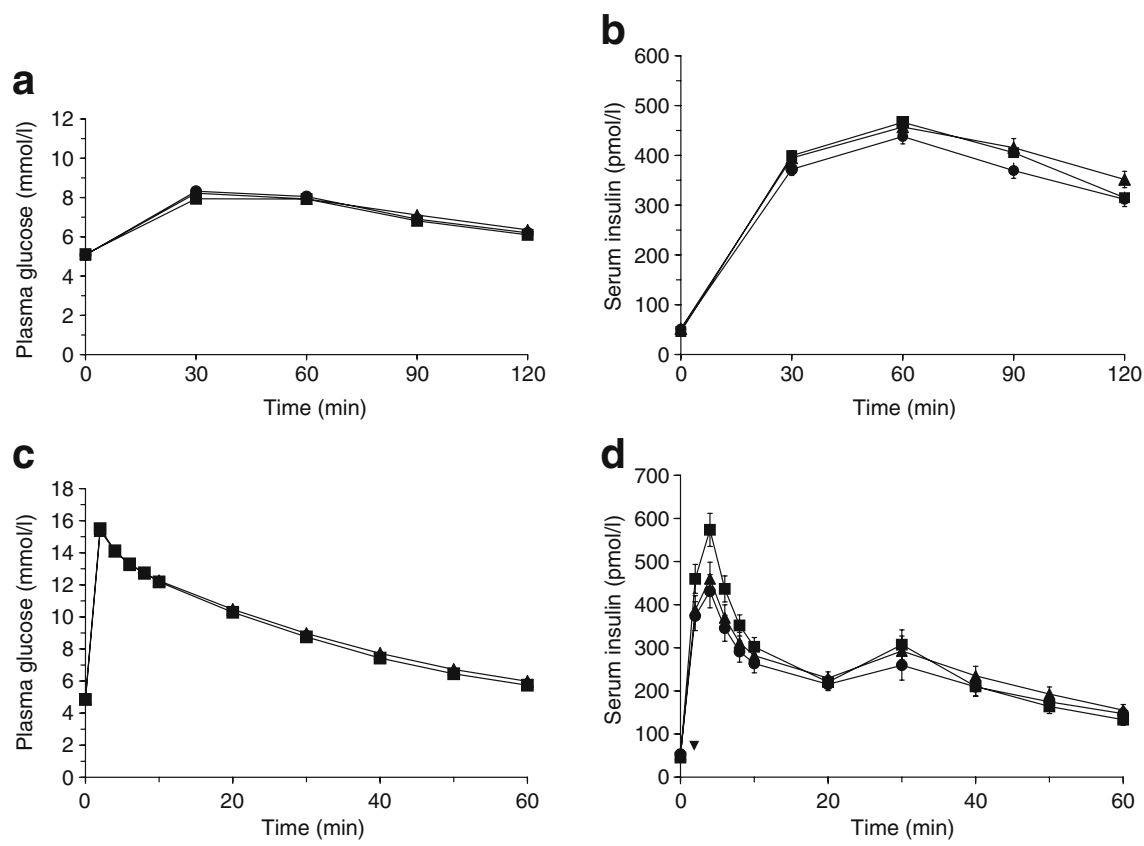
cells via paracrine/autocrine interactions. A previous report indicates that zinc released from activated insulin-secreting beta cells is implicated in the suppression of glucagonsecretion in neighbouring alpha cells [24]. It has also been suggested $[10,21,25]$ that excessive apoptosis of the pancreatic beta cells is associated with diabetes, and since zinc is a potent inhibitor of apoptosis, zinc depletion by itself can enhance apoptosis in beta cells [21]. Thus, the SLC30A8 C allele might not only cause a decrease in insulin release, but may also lead to decreased beta cell mass via increased apoptosis. In addition, overexpression of SLC $30 A 8$ in insulinoma cells has been shown to increase glucose-stimulated insulin secretion [18]. Therefore, stimulating ZnT-8 production and/or activity may potentially be a novel approach in the treatment of type 2 diabetes patients, in whom zinc depletion is likely to participate in both acute and chronic beta cell dysfunction [18].

In conclusion, in non-diabetic but diabetes-prone European offspring of one type 2 diabetic patient, homozygous carriers of the Arg325Trp polymorphism in ZnT-8 are characterised by a $19 \%$ reduced first-phase serum insulin response following an intravenous glucose challenge. This finding underscores the hypothesis that variation in $\mathrm{ZnT}-8$ is a cause of impaired pancreatic beta cell function and thereby modulates insulinaemia.

Acknowledgements This study was supported by the EUGENE2 project, which is funded by the European Community (LSHMCT-2004-512013), and by the FOOD Study Group/Danish Ministries of Food, Agriculture and Fisheries, and Family and Consumer Affairs (grant no. 2101-05-0044).

Duality of interest The authors declare that there is no duality of interest associated with this manuscript.

\section{References}

1. Wray LA, Ofstedal MB, Langa KM, Blaum CS (2005) The effect of diabetes on disability in middle-aged and older adults. J Gerontol A Biol Sci Med Sci 60:1206-1211

2. Permutt MA, Wasson J, Cox N (2005) Genetic epidemiology of diabetes. J Clin Invest 115:1431-1439

3. Sladek R, Rocheleau G, Rung J et al (2007) A genome-wide association study identifies novel risk loci for type 2 diabetes. Nature 445:881-885

4. Steinthorsdottir V, Thorleifsson G, Reynisdottir I et al (2007) A variant in CDKAL1 influences insulin response and risk of type 2 diabetes. Nat Genet 39:770-775

5. Scott LJ, Mohlke KL, Bonnycastle LL et al (2007) A genomewide association study of type 2 diabetes in Finns detects multiple susceptibility variants. Science 316:1341-1345
6. Saxena R, Voight BF, Lyssenko V et al (2007) Genome-wide association analysis identifies loci for type 2 diabetes and triglyceride level. Science 316:1331-1336

7. Omori S, Tanaka Y, Takahashi A et al (2008) Association of CDKAL1, IGF2BP2, CDKN2A/B, HHEX, SLC30A8 and KCNJ11 with susceptibility to type 2 diabetes in a Japanese population. Diabetes DOI 10.2337/db07-0979

8. Horikoshi M, Hara K, Ito C et al (2007) Variations in the HHEX gene are associated with increased risk of type 2 diabetes in the Japanese population. Diabetologia 50:2461-2466

9. Zeggini E, Weedon MN, Lindgren CM et al (2007) Replication of genome-wide association signals in U.K. samples reveals risk loci for type 2 diabetes. Science 316:1336-1341

10. Chimienti F, Devergnas S, Favier A, Seve M (2004) Identification and cloning of a beta-cell-specific zinc transporter, ZnT-8, localized into insulin secretory granules. Diabetes 53:2330-2337

11. Chausmer AB (1998) Zinc, insulin and diabetes. J Am Coll Nutr 17:109-115

12. Chimienti F, Favier A, Seve M (2005) ZnT-8, a pancreatic betacell-specific zinc transporter. Biometals 18:313-317

13. Pascoe L, Tura A, Patel SK et al (2007) Common variants of the novel type 2 diabetes genes CDKAL1 and HHEX/IDE are associated with decreased pancreatic beta-cell function. Diabetes 56:3101-3104

14. Staiger H, Machicao F, Stefan N et al (2007) Polymorphisms within novel risk loci for type 2 diabetes determine beta-cell function. PLoS ONE 2:e832

15. DeFronzo RA, Tobin JD, Andres R (1979) Glucose clamp technique: a method for quantifying insulin secretion and resistance. Am J Physiol 237:E214-E223

16. Pacini G, Bergman RN (1986) MINIMOD: a computer program to calculate insulin sensitivity and pancreatic responsivity from the frequently sampled intravenous glucose tolerance test. Comput Methods Programs Biomed 23:113-122

17. Matthews DR, Hosker JP, Rudenski AS, Naylor BA, Treacher DF, Turner RC (1985) Homeostasis model assessment: insulin resistance and beta-cell function from fasting plasma glucose and insulin concentrations in man. Diabetologia 28:412-419

18. Chimienti F, Devergnas S, Pattou F et al (2006) In vivo expression and functional characterization of the zinc transporter ZnT8 in glucose-induced insulin secretion. J Cell Sci 119:4199-4206

19. Seve M, Chimienti F, Devergnas S, Favier A (2004) In silico identification and expression of SLC30 family genes: An expressed sequence tag data mining strategy for the characterization of zinc transporters' tissue expression. BMC Genomics 5:32

20. Dodson G, Steiner D (1998) The role of assembly in insulin's biosynthesis. Curr Opin Struct Biol 8:189-194

21. Emdin SO, Dodson GG, Cutfield JM, Cutfield SM (1980) Role of zinc in insulin biosynthesis. Some possible zinc-insulin interactions in the pancreatic B cell. Diabetologia 19:174-182

22. Gold G, Grodsky GM (1984) Kinetic aspects of compartmental storage and secretion of insulin and zinc. Experientia 40:1105-1114

23. Qian WJ, Aspinwall CA, Battiste MA, Kennedy RT (2000) Detection of secretion from single pancreatic beta-cells using extracellular fluorogenic reactions and confocal fluorescence microscopy. Anal Chem 72:711-717

24. Ishihara H, Maechler P, Gjinovci A, Herrera PL, Wollheim CB (2003) Islet beta-cell secretion determines glucagon release from neighbouring alpha-cells. Nat Cell Biol 5:330-335

25. Zalewski PD, Millard SH, Forbes IJ et al (1994) Video image analysis of labile zinc in viable pancreatic islet cells using a specific fluorescent probe for zinc. J Histochem Cytochem 42:877-884 